\title{
INVESTIGATION OF BIOFUEL PRODUCTION POSSIBILITIES FOR STABILISATION OF AGRO-INDUSTRIAL COMPLEX OF UKRAINE
}

\author{
Hryhorij Kaletnik $^{1}$, Irina Pilvere ${ }^{2}$, Stanislav Nikolaenko ${ }^{3}$, Volodymyr Bulgakov ${ }^{3}$ \\ ${ }^{1}$ Vinnytsia National Agrarian University, Ukraine; ${ }^{2}$ Latvia University of Agriculture , Latvia; \\ ${ }^{3}$ National University of Life and Environmental Sciences of Ukraine, Ukraine \\ semjons@apollo.lv
}

\begin{abstract}
Assessment of the fuel and energy sector and the cost dynamics of the traditional kinds of fuel in the world and in Ukraine has been carried out. An analysis has been executed of the export indicators of the main agricultural crops, which are potential raw materials for the production of biofuel. A necessity has been substantiated to adjust the production of bioethanol, biodiesel and biogas on the territory of Ukraine in order to ensure stable functioning of agricultural production and provision of fuel and biogas for the population and the agricultural complex of the country. The potential of biogas production from corn for silage has been determined. Assessment of the operation of the beet sugar complex of Ukraine is carried out. Peculiarities of biofuel production in the countries that are the world leaders in the field of renewable energy are considered.
\end{abstract}

Keywords: energy security, resource potential, biogas, biofuel.

\section{Introduction}

Energy is the basis for the economical development of each state. The share of import in the balance of energy resources of Ukraine in 2013 was 60-65 \% [1]. If before 2013 the country had to solve only the problem of the high cost of the imported natural gas, now the question of the possibility and conditions for its import, as well as the supply of the required quantity of coal at relatively lower prices, is in question.

At the present time, there is also an imbalance in the work of the agro-industrial complex, a disparity in the prices for energy, industrial and agricultural products, deterioration of the cultivation culture in agriculture and a negative trend in the priority cultivation of the export-oriented crops.

In 2013, Ukraine occupied the 6th place in the world in grain production, producing 63 million tons of grain (of which $40 \%$ or 25 million tons were exported) [1]. The high share of grain exports, as a rule, is not an indicator of a good state of a country's economy, even for countries with welldeveloped grain production. So, the world leader in the production of grain at that time was the USA 378.3 million tons, yet the volume of exports was only $18.5 \%$ (70.1 million tons). A large amount of fodder grain and canola (rapeseed) seeds exported from Ukraine is processed there into biofuel.

In 2013, by the volume of corn production, Ukraine took the 7th place in the world, producing 31 million tons. At the same time, the exports constituted $61.3 \%$ of the total production. For comparison, the USA produced 320 million tons of corn, while the exports were only 13.5 percent [1].

The USA owns the largest oil reserves in the world, but every year they increase the amount of corn processed into bioethanol. If in 2000 the USA processed only $10 \%$ of the total corn harvest into bioethanol, then in 2013 this volume was $40 \%$. Besides, the starch-containing part of the corn grain is used for the production of bioethanol, but the by-product of processing, i.e. protein is used for fattening cattle.

The production of biogas in individual biogas reactors has grown to an impressive extent in China, where there are more than 35 million biogas plants today recycling into biogas all livestock and plant waste products. The fermented waste is no longer dangerous to the environment, but at the same time they make it possible to obtain environmentally friendly biogas and organic fertilisers. Thus, China, producing livestock products in the individual sector, in addition obtains more than 25 billion cubic meters of biogas. In Germany, there are now about 2 thousand large biogas plants that produce biogas from corn silage.

For the first time mass production of bioethanol started in Brazil in order to stabilise the situation in the sugar market and to reduce the dependence on the oil import. There, already in 1933, a law was passed on the recommended addition of bioethanol to gasoline. Since then bioethanol production has increased 49-fold.

Considering the problems that have arisen at the present stage of the country's development, it is necessary to seek solutions to reduce energy dependence on imports of energy resources, including the 
production of biofuel from agricultural products. For the Ukrainian agricultural economy it is important to make a choice - which is more profitable: to be a supplier of raw materials or to try to recycle them at home. The latter means additional hundreds of thousands of jobs, income for the citizens and the state budget, a sharp decrease in the country's dependence on energy carriers. By exporting agricultural raw materials we give an opportunity to benefit to other countries but Ukraine's own economy receives very little from this. However, these profits practically do not go into the state budget. At the same time, Ukraine is forced to take credits from the International Monetary Fund at high rates and fulfil its demands to raise the retirement age, utility tariffs, taxes, etc.

The issues of the resource potential of the agro-industrial complex and the development of the biofuel production have been the topic of the scientific works by many leading Ukrainian scientists, in particular, M. Roik, I. Kirilenko, S.T. Oleinichuk, Y. Blum, and many others [2-7]. So far the facilities the production of biodiesel from rapeseed oil and other vegetable seed oils in the world particularly in Ukraine have made extensive studies.[8; 9].

The economic component of the functional-role and content characteristics of the biofuel industry as one of the forerunners of national energy security have been disclosed in the research by V.Ya. Mesel-Veselyaka, O.M. Shpichak, S.M. S.M. Kulagi [10-12]. The issues of intensification of the production and consumption of biogas and biofuel have been studied in many works of scientists in Europe and the world [13-15]. However, further research needs stabilisation of the work of Ukraine's agro-industrial complex through debugging the production and consumption of biofuel. This result can be achieved by reorienting the export-oriented management of agriculture in Ukraine to the biofuel production within the country.

\section{Materials and methods}

The purpose of the work is to justify the need for the intensification of the biofuel production in Ukraine in order to stabilise the work of the agro-industrial complex and to ensure energy, economic, environmental and food security of the country.

To assess the potential of the Ukrainian agriculture for the production of biofuel, an analysis was made of the possibilities to use corn and sugar beet for these purposes. The potential for the production of biogas from silage corn, which can be grown on the land occupied by corn to be exported, was determined by calculation. Variation in the national currency (Ukrainian hryvnia - UAH) of Ukraine from 2000 to 2017 is shown in Fig. 1.

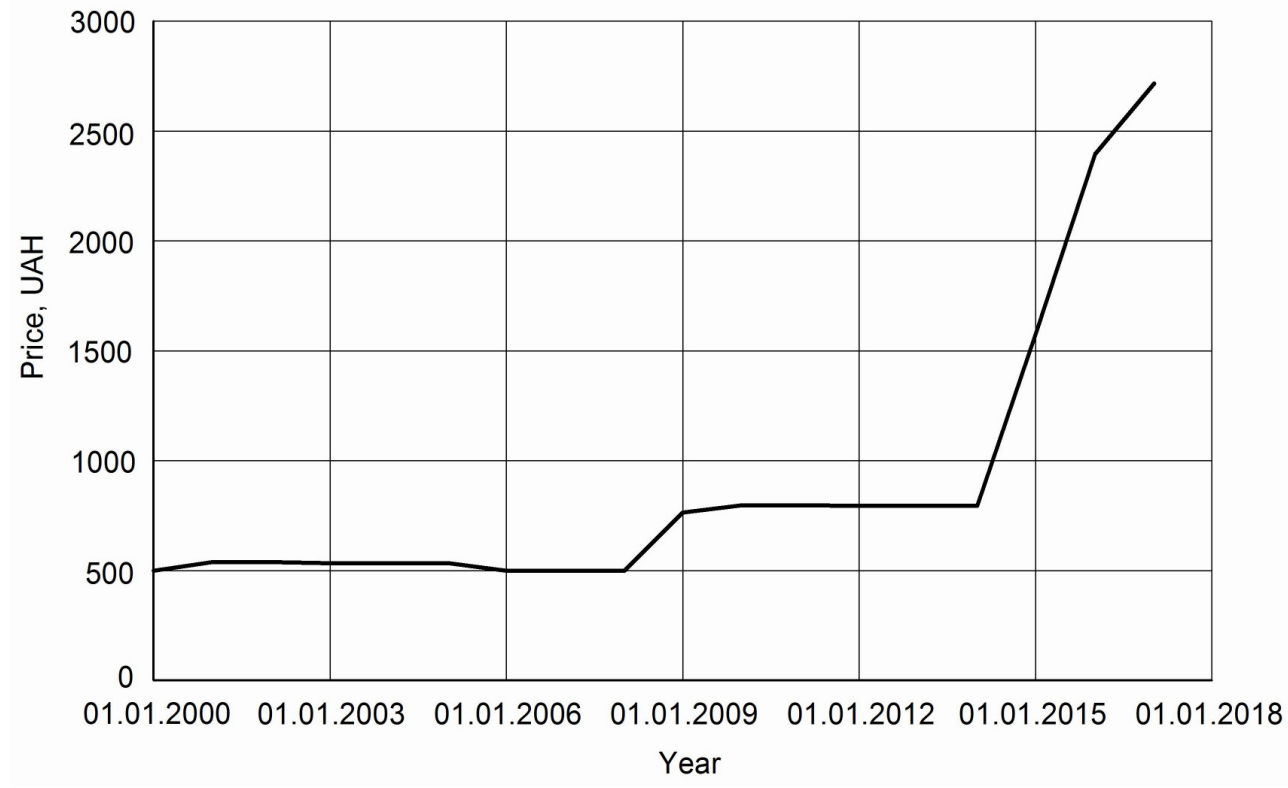

Fig. 1. Graph of the variation in the exchange rate of the hryvnia (UAH) against USD 100 from 2000 to 2017

Methods of economic analysis and statistical data processing have been applied in the work. In the calculations there were used data from the Ministry of Agrarian Policy and Food of Ukraine, the 
Verkhovna Rada Committee of Ukraine on the issues of Agrarian Policy and Land Relations, the State Statistics Service of Ukraine, the "UkrNIIpirtbioprod".

To analyse some of the indicators, the year 2013 was chosen, which was not heavily affected by political and economic activities in Ukraine, and it can be considered as the most characteristic for the Ukrainian economy under the conditions of the pre-reform environment.

\section{Results and discussion}

At present, the renewable energy in the structure of Ukraine's energy supply constitutes only $3 \%$, the largest part being natural gas (Fig. 2). In recent years, there has been a trend in Ukraine's energy supply to reduce the share of natural gas from 37 to $29 \%$, the shares of coal - from 33 to $30 \%$ (which is mainly explained by the international situation), and to increase the renewable sources of up to $3 \%$.

a)

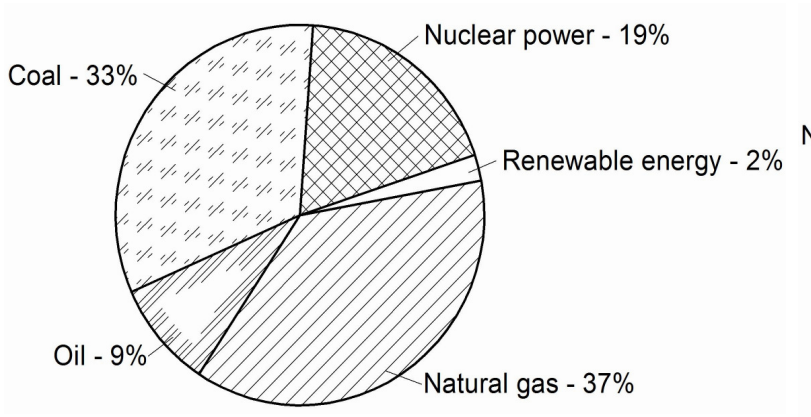

b)

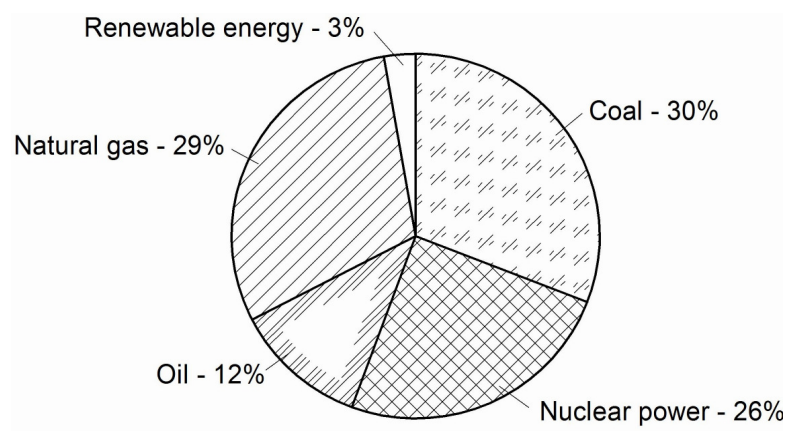

Fig. 2. Structure of the total supply of primary energy in Ukraine in 2013 (a) and 2015 (b)

According to the data of the Ministry of Agrarian Policy and Food of Ukraine, the average annual demand of an agro-industrial complex in light oil products is, on the average,: in diesel fuel - 1 million 870 thousand tons, in gasoline - 620 thousand tons. By the prices of the year 2000, for the purchase of such quantities of diesel fuel and gasoline, the costs were 4363 million UAH, in 2014 they amounted to 35785 million UAH (Table 1). The source: own calculations based on the data from the State Statistics Service of Ukraine. [1]. Undoubtedly, during this time there took place devaluation of the local currency in Ukraine, the cost of fuel increased 8 times, while the sales of sugar beet, grain, meat and milk increased by 3.3-4.1 times. Obviously, such a disparity of prices leads to a decrease in the profitability of agricultural production.

Wholesale value of gasoline and diesel fuel

Table 1

\begin{tabular}{|c|c|c|c|}
\hline Parameter & Year 2000 & Year 2014 & Year 2016 \\
\hline Cost of gasoline, $\mathrm{UAH} \mathrm{t}^{-1}$ & 1850 & 17000 & 21900 \\
\hline Consumption of gasoline, thousand $\mathrm{t}$ & 620 & 620 & 620 \\
\hline Cost of diesel fuel, UAH t ${ }^{-1}$ & 1720 & 13500 & 17200 \\
\hline Consumption of diesel fuel, thousand $t$ & 1.870 & 1.870 & 1.870 \\
\hline Total costs, billion UAH & 4.363 & 35.785 & 45.742 \\
\hline Increase in costs in comparison with 2000 , billion UAH & - & 31.422 & 41.379 \\
\hline
\end{tabular}

If we do not take into account the fall in the prices of oil and its processed products in the world in 2008 (the beginning of the recession in the world economy) and after the collapse of prices in 2014, then the dynamics of the cost of traditional fuels, on the whole, in Ukraine is characterized by constant growth (Fig. 3). The source: formed on the basis of the data of the Biofuel Platform Statistical Review of the World Energy and the Ministry of Energy and Coal Industry of Ukraine [1].

In any case, the growth in the prices of the fuel and energy carriers is much faster than the sales prices of the manufactured goods (used as raw materials for export, etc.) and the growth of the indicators of the people's well-being. 
The high fuel prices have a negative influence on the interest in growing agricultural crops, especially which need to spend a huge amount of oil products. Thus, it becomes not profitable to sell agricultural products in the form of raw materials. The efficiency and interest of agricultural producers could be increased by processing excess agricultural products into biofuel.

In Europe, for the production of biogas, mainly corn silage and livestock waste are used. In contrast to other energy crops, corn silage has advantages due to the relatively lower costs of growing and storage. Besides, the production of biogas from corn silage is characterised by the reduction of the greenhouse gas emissions and a high fuel economy [15-17] Also, ensilaged corn can be preserved on the field for up to one year with low losses in the dry mass. In recent years, the average yield of silage corn in the agroformations of Ukraine is 35.0-36.0 $\mathrm{t} \mathrm{ha}^{-1}[3 ; 6]$. Consequently, only on 2 million hectares of agricultural land, actually intended for the export of grain corn, we can produce up to 26 billion cubic meters of biogas in Ukraine (Table 2) and thus solve the problem of sharp dependence on natural gas imports, and also create additional jobs and income to the state budget. In addition, the location of biogas plants in regions where silage from corn is produced can solve the gasification problem of the villages.

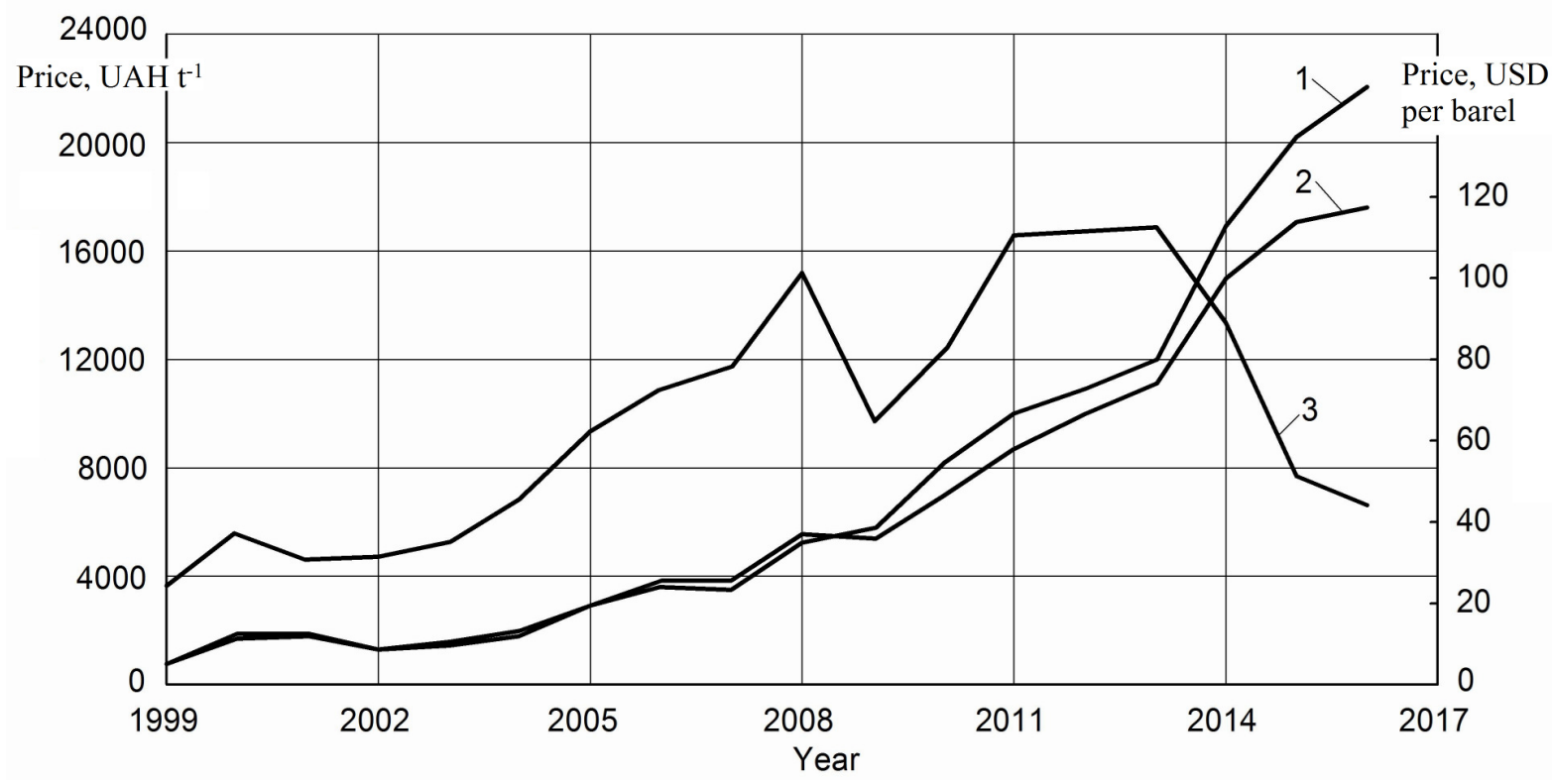

Fig. 3. Prices of oil, gasoline and diesel fuel in Ukraine: 1 - price of gasoline, $\mathrm{UAH} \cdot \mathrm{t}^{-1}$; 2 - average price of diesel fuel, $\mathrm{UAH} \cdot \mathrm{t}^{-1} ; 3$ - price of oil, USD per barrel

Table 2

Potential for the biogas production from corn for silage in Ukraine in 2013

\begin{tabular}{|c|c|}
\hline Indicator & Value \\
\hline Production of corn for grain, million $\mathrm{t}$ & 31 \\
\hline Yield of corn for grain, $\mathrm{t} \cdot \mathrm{ha}^{-1}$ & 6.4 \\
\hline Export of corn grain, million $\mathrm{t}$ & 19 \\
\hline Area of under corn intended for export, thousand ha & $2,968.750$ \\
\hline Yield of corn for silage, $\mathrm{t} \cdot \mathrm{ha}^{-1}$ & 35.0 \\
\hline $\begin{array}{c}\text { Potential yield of corn, which can be used for biogas production } \\
\text { (instead of grain export), million t }\end{array}$ & 103.9 \\
\hline Output of biogas, $\mathrm{m}^{3} \cdot \mathrm{t}^{-1}$ of silage corn & - \\
\hline Potential of biogas production, million $\mathrm{m}^{3}$ & 25976 \\
\hline
\end{tabular}

The prime cost of corn for silage in 2014 was $160 \mathrm{UAH} \cdot \mathrm{t}^{-1}$. Taking into account that the output of biogas from 1 ton of silage is about $250 \mathrm{~m}^{3}$, the prime cost of $1000 \mathrm{~m}^{3}$ of biogas made from silage corn will be no more than USD 100. This figure is calculated on the basis of the cost of the raw material and the cost of processing, as well as other costs, including taxes. 
The grain corn exported from Ukraine to the countries of Western Europe is also partly processed into bioethanol. At the same time, Ukraine annually buys more than half of the demand for light oil products and more than 25 billion $\mathrm{m}^{3}$ of natural gas. Such a situation logically aims at reorienting and searching for more efficient ways how to use agricultural products for fuel production.

In general, on the areas for growing grain corn for export it would be much more expedient to grow corn for silage and produce biogas from it, as it is done in Germany and China, which are the leaders in the number of biogas plants in the world on the land used to grow grain for export.

By calculation it has been established that $1000 \mathrm{~m}^{3}$ of biogas from silage corn in Ukraine will not be more expensive than USD 100. In reality, there is no point in counting on state benefits and subsidies at this stage, and, in fact, the manufacturers do not need this. Replacing the part of the grain corn by silage corn will allow the state to preserve its export potential and reduce the costs of currency for the gas imports and increase energy independence.

Another problem in the agro-industrial complex of Ukraine is the instability of functioning of the beet-sugar complex. The fluctuation of prices in the sugar market, the limited external markets for the final products and the import of sugar and sugar substitutes into Ukraine led to the imbalance of sugar beet production and the closure of many sugar refineries. In 2000, 146 sugar refineries were engaged in the processing of sugar beet in Ukraine. In 2012, this number decreased to 63. In order to support this sector of economy, the Government of Ukraine has developed various programs: from purchases in the State Reserves and the Agrarian Fund to direct financial compensation from the State Budget in the amount of UAH 750 for each sown hectare of sugar beet. Yet, these measures have not solved the problem of a stable interest of beet-growing farms and sugar factories. Ukraine annually produces about 2 million tons of sugar and, in general, there is a constant surplus in the domestic market. Since the fall in prices with a high gross harvest of the beet raw materials and a rise in prices with its deficit, constantly worsen the industry, it creates uncertainty and economic losses. One of the most efficient instruments for the stabilisation of the sugar beet industry, its economic efficiency, could be introduction of a technology for the simultaneous processing of sugar beet into sugar and bioethanol.

A negative pressure upon the domestic sugar market is caused also by the import of raw sugar from sugar cane. As a member of the World Trade Organization, Ukraine has pledged to import 260,000 tons of raw sugar a year without applying import restrictions. This is determined by the Decree of the Cabinet of Ministers of Ukraine of December 27, 2008 No. 11225 "On the use of sugar produced from raw sugar from cane which is imported to Ukraine within the established tariff quota." The preferential duty rate is set at $2 \%$ (against $50 \%$ on a general basis). Therefore, there is a question of surplus sugar in the domestic market. The pressure upon the sugar market is exerted by the uncontrolled import of sugar substitutes, which are widely used in the food industry. Synthetic sweeteners are attractive for manufacturers of confectionery and sugary drinks due to cheaper prices. Although the official statistics of the turnover of sweeteners is not carried out, according to the data of "Ukrsakhar", in 2010-2011, they were imported to Ukraine in a volume, which replaces 250-300 thousand tons of sugar (10-15\% of the sugar market). Every year the import of sweeteners continues growing. But in general, the possibilities for cultivating and processing sugar in Ukraine are more than 2.5 times higher than today's volumes.

A certain solution to reduce the imbalance of agro-industrial production may become introduction of the biofuel (bioethanol) production. Many advanced countries have already chosen this path, and here it is necessary to take advantage of the best proven experience $[3 ; 5 ; 14 ; 19]$.

The greatest volume of bioethanol production $\left(75001 \mathrm{ha}^{-1}\right)$ can be obtained from sugar beet. In France, sugar factories are being built which produce sugar, food grade alcohol and bioethanol. An example is the Cristanol plant, which cooperates with 6000 farmers. At the same time, an uninterrupted supply of raw materials to the plant is ensured, and for the farmers - a stable place for selling their products at profitable prices. Being built using the funds of the state, farmers and investors, the plant, worth 280 million Euros, is capable of processing 21,000 tons of sugar beet per day. The peculiarity is that sugar beet is processed into sugar, bioethanol and food alcohol on a single production plant. There is a possibility on the plant to regulate the production volumes of one or another product taking into account the current situation on the market. For instance, if an 
unfavourable situation arises for the sale of sugar in the market, then more raw material is sent to the Cristanol plant for the production of bioethanol, and vice versa.

At the current conditions in Ukraine from one hectare of rapeseed sowings 1.5 to 2.0 tons of diesel fuel can be obtained. In theory, to ensure Ukraine's agriculture with the necessary amount of diesel fuel, in the existing sown area is a need to increase rape sown areas by 6-8\%. In order to maintain the gross grain yield, it is necessary to increase the grain yield of $6-8 \%$, which is quite realistic.

The economic and social need for the formation and development of the biofuel market in Ukraine is justified for several reasons, starting from the considerations of energy security, diversification of national production, support for innovations, and ending with the economic and social efficiency of the biofuel market development on the basis of high motivation for the growth of the agricultural sector, a positive social shift in relation to the growth of employment of the rural population and ecological security due to renewable sources of energy.

The production and use of biofuel in Ukraine's agriculture is an objective prerequisite for creating additional jobs, increasing employment of the rural population, increasing the efficiency of production and well-being of the peasants. After all, the overwhelming majority of the processing enterprises are located in rural areas, and for some localities they are the main payers of taxes to local budgets. On their basis the social and household infrastructure of rural settlements is built, and the irregular operation of the processing factories painfully hits exactly the most vulnerable layers of the population leading, by the way, to problems with the provision of kindergartens, schools, and dwelling houses with heat and electricity.

Solving the problem of dynamic production of biofuel needs to create a market for energy crops as raw materials for its production, to use agricultural lands, which are suitable for growing energy crops, without reducing the level of food production. There is a constant discussion on this subject: what is more important - food or biofuel? This problem is very complicated because, on the one hand, provision of the population with food is a priority for each government, and, on the other hand, the energy independence of the country is the basis of its sovereignty. Therefore, the analysis of the possibilities for growing bio-raw materials to produce biofuel should be conducted taking into account the actual market situation with the existing requirements for food products, as well as with the existing sources of fuel supply for both the state, in general, and its individual regions.

\section{Conclusions}

1. Strong dependence on the energy import, the rising prices for fuel energy, deterioration of the environmental situation, inefficient export of agricultural products and the high unemployment rates in rural areas are major risk factors for the economy of the Ukrainian agro-industrial complex.

2. Introduction of the biofuel production in Ukraine from corn and sugar beet could stabilise the development of the agro-industrial complex, ensure strengthening of the country's energy independence, create new jobs and, on the whole, improve the economic situation.

\section{References}

1. State Statistics Service of Ukraine documents publishing [online][11.12.2017] Available at: https://ukrstat.org/en

2. Калетнік Г.М. Розвиток ринку біопалива в Україні (Development of the biofuel market in Ukraine). Монографія. Kуiv, 2008, 464 p. (In Ukrainian).

3. Блюм Я., Гелетуха Г., Григорюк І., Дубровін В. та ин. Новітні технології біоенергоконверсії (New bioconversion technologies). Монографія. Kуiv, 2010, 326 p. (In Ukrainian).

4. Роїк М. Біопаливо як загальнонаціональний пріоритет розвитку агропромислового комплексу (Biofuel as a priority for the development of the agro-industrial complex) Біопаливо як загальнонаціональний пріоритет розвитку агропромислового комплексу. Наука та наукознавство. 2006, No 3, pp. 118-121. (In Ukrainian).

5. Олійнічук С., Левандовський Л., Шевченко В. Технологічний регламент виробництва етилового спирту з крохмалевмісної сировини (Technological regulations for the production of ethyl). Kyiv, 2000, 142 p. (In Ukrainian). 
6. Блюм Я., Гелетуха Г., Григорюк І. Біологические ресурсы и технологии произвлодства биотоплива (Biological resources and technologies for the biofuel production). Kyiv, 2010, 408 p. (In Ukrainian).

7. Гейд О.П., Ковтун А.П. Виробництво дизельного біопалива (Production of diesel biofuel), Вісник Полтавської державної аграрної академії, 2010, № 4, pp. 190-195. (In Ukrainian).

8. Ediger V., Kentel E. Renewable energy potecial as an alternative to fossil fuels. Energy Conversion \& Management, 40. 1999, pp. 743-755.

9. Viesturs D., Melece L. Advantages and disadvantages of biofuels: observations in Latvia. Engineering for Rural Development, Proceedings, Vol. 13, 2014. pp. 210-215

10. Калетнік Г. М. Біопаливо. Продовольча, енергетична та екологічна безпека України (Biofuel. Food, energy and ecological security of Ukraine): Монографія. Куіv, 2010, 516 p. (In Ukrainian).

11. Месель-Веселяк В. Я., Паштецький В. С. Ефективність застосування альтернативних видів енергії в сільському господарстві України (Efficiency of using alternative kinds of energy in Ukraine). Економіка АПК, 2011, No 12, pp.3-9. (In Ukrainian).

12. Трипольська Г. Агробіоенергетичний ринок України (The agro-bioenergy market of Ukraine) Монографія, 2011, Куiv, 264 p. (In Ukrainian).

13. Maier S., Szarencsits M., Shahzad K. Ecological evaluation of biogas from catch crops with Sustainable Process Index. Energy, Sustinability and Society, Vol.7, Issue 1, 2017, No 4.

14. Narodoslawsky M., Niederl-Schmidinger A., Halasz L. Utilizing renewable resources economically: new challenges and chances for development. Journal of Cleaner Production, 16 (2), 2008, pp. 164-170.

15. Szerencsits M. Biogas aus Zwischenfrüchten: Ein Beitrag zum Klimaschutz und zur Erhöhung der Wertschöpfung bei gleichzeitiger Sicherung der Lebensmittel versorgung. Syn-Energy, no 4, 2009 (https://www.klimafonds.gv.at/assets/Uploads/Veranstaltungen/2012/Science-Brunch3.3/KLIEN-2SynEnergyOekocluster.pdf).

16. Ayhan A. Biogas potential from waste of Marmara region-Turkey. Agronomy Research, 2016, 14 (3), pp. 650-660.

17. Iglinski B., Buczkowski R., Cichosz M. Biogas production in Poland-current state, potential and perspectives. Renewable and Sustainable Energy reviews 50, 2015, pp. 686-695.

18. Rivža S., Rivža P., Pilvere I., Rivža B. Dynamic model of the farm producing biogas from agriculture. WMSCI 2012 - The 16th World Multi-Conference on Systemics, Cybernetics and. Informatics, Proceedings.Vol.1, 2012, pp.81-84

19. Ramirez-Velasquez A., Montoya R. Analysis of marketing mix model of the bioethanol industry in Colombia . Acta Agronomica, Vol.61, Issue 2, 2012, pp. 177-191. 